\title{
EQUITY'S DIFFERENT TALKS
}

\section{Cristina Costantini}

Equity is anything but monolithic. The title of my paper Equity's different talks - intends to go back to the fundamental ambiguity that lays at the roots of Equity both as a word and as a set of ideas, and at the same time it predicts the peculiarity of English Legal System, where the original complexities resulted in a real antagonism among different institutions, converting the ontological dispute in a matter of politics.

The inquiry faces multifarious levels of questions: from the detection of the ubiquitous notions connected with equity (a kind of Foucaultian archaeology), to the critical comprehension of the traditions that shaped the wandering soul of equity into heterogeneous appearances of coherence, passing through the analysis of the pivotal role played by equity in the creation of clashing cultures each of them with its proper discursive structure. So, once again, the history of genealogies is combined with the rhetoric of Power.

Moreover the rediscovery of the hybrid nature of equity, as it was inherited by English legal thought, allows us to unveil many other problematic sides that are eclipsed in conventional narratives. 
The theological dimension deeply defines the boundaries of early modern concept of equity recalling its scriptural foundation as a means of justification and the complex cluster of terms used by the different versions of the Bible (respectively the Hebrew Bible, the Septuagint and the Vulgate) to represent the core of Christian equity.

In this perspective from the beginning equity has moulded its own literary representation, imposing specific structures of expression, precise patterns of writing and selected figures of speech. In the light of the origins it is possible to better understand Equity as a poetic subject dealing with different genres and involving a rich verbal texture.

There is another point I'd like to stress in my preliminary remarks.

Studying the history of English legal system through the philosophical - not only legal - accounts I became persuaded that English Equity, developed from the intersection of Greek, Roman and Christian traditions, represented the perfect and powerful incarnation of the paradigm of political theology.

The demarcation of the institutional and theoretical difference between Law and Equity, the struggle between the oracles of the Law and the defenders of Equity, the sacramental function of the Chancellor as the religious keeper of the King's conscience, the reinterpretation of the ancient equity as a modern instrument to 
support royal prerogatives and to compose an original royal ideology, all these elements contribute to plot the history of an inner and unique dialectic that closely relates the spheres of theology, law and politics and strongly directs the mutual relations, so to forge the respective domains in a tension for long time unresolved. In my view the creation of an English instituzionalized Equity reconciles the opposite ways of thinking political theology that set up Schmitt's opinion against Assmann's one else.

With this assertion I'd like to underline how the singular, distinctive conditions that marked the history of early modern England made possible both the translation of theological concepts into lay or secularized concepts (according to Schmitt's theory) and in the transposition of political concepts into religious ones (according to Assmann's thought). From my own perspective this is a kind of elected field of research which can shape a new course for the critical understanding of the really involved notion of secularization.

Therefore, speaking about equity's different talks, I want to explore various aspects, pointing out their strong connection:

1) on a linguistic level: I'd like to stress the literary pliability of equity as it emerges from the classical and biblical sources and the consequent abstraction of its multiple and polymorphic roots into a movable concept;

2) on a methodological level: I'd like to focalize my attention on the specific aims of interdisciplinary approach when we are dealing with the real mastery of equity; 
3) on historic but also legal and philosophical level: I'd like to reconsider (or rethink) the singularity of the English solution insofar as Equity became the fundamental point of intersection of Renaissance humanism and Reformers' purposes.

For these reasons, if Selden could define Equity as a roguish thing, I'd like to investigate the concept of equity as a 'factor of revolution' which marked the history of the Western Legal Tradition, in the meaning given to the word 'revolution' by Harold J. Berman.

1. Starting from the origins, and looking at the etymology of the word Equity, as a translation of the latin aequitas, it is possible to disclose the real contribution both of Latin and of Greek world to the creation of equity meant as a masterpiece of the English (not only legal) culture. In fact, in spite of the etymology, the concept of Equity (English equity) is a translation of the Greek idea of epieikeia much more than of the latin aequitas: so the set of associations of different, linguistic and conceptual elements reintroduces the issue of the roots of Western tradition when it ends up as equity in English.

In Plato and Aristotle we can find the groundwork for the legal notion of equity and a significant number of concepts that will reappear in later thinking about equity.

In Aristotle's Ethics and Rhetoric the notion of epieikeia is defined by the means of opposition pairs:

firstly to grasp its proper relation with positive law; 
- $\quad$ secondly to recall the question of the ontological and practical difference between positive law and natural justice, becoming a synonymous of universal justice.

In Plato's Laws we can find the same technique of definition with reference to the corresponding adjective epieikés:

- $\quad$ in a first meaning it qualifies the decent man opposed to the evil man, to connote 'one who has become experienced and decent through habituation';

- $\quad$ coupled with forgiveness, the same adjective denotes a very reduction 'of the perfection and exactness that belong to strict justice', so to introduce the distinction between epieikeia and dike or themis (that is justice) giving to the first idea (epieikeia) the function of mitigating and adapting every epiphany of strict justice (I mean, not only strict legal justice).

Plato's Statesman raises a further and basic question: what kind of limits can be set to discretion in the face of Law? This is the fundamental issue which will orient the later discussions about legal equity.

So the idea of epieikeia drew the specific feature of classical culture opposing the universal nature of the Law with the historicity of actual facts and representing the tragic side of human behaviour on the ground of an unsolvable conflict between duties.

But the history of ideas is never univocal. 
The classical pattern of epieikeia has to be connected to the biblical notion of equity. The Hebrew word in the text of the Hebrew Bible that can be translated with equity is mesarim, another complex term, a plural noun which derives from the root $y s r$.

Now, as it has been said, the history of translation of the Hebrew Bible is a complex story of the appearance and disappearance of word for equity.

The early Greek translation, the Septuagint, does not translate mesarim as epiekeia, but in a number of other ways and especially making use of the term euthutes, from euthus, straight righteousness. The Vulgate, the most important Latin Bible, regularly has aequitas as a translation of mesarim (for example in Psalms and Proverbs), but there is no a perfect correspondence between the two words, so that mesarim is not always translated with aequitas (for ex in Psalms 99:4) and reciprocally aequitas is sometimes used where there is no mesarim in the Hebrew Bible (for ex. in Isaiah 11:4).

This remark is interesting if we turn our attention to the early modern translations of the Bible into other vernaculars and especially to the seven major translations into English. I perfectly agree with Mark Fortier when he underlines that all the various versions of Old Testament influenced the modern translations; each of them - I add became a different 'formant of legitimation': the Hebrew Bible in the name of its authenticity, the Greek because of its antiquity and finally the Latin for its authority. So, as a consequence, Equity's compelling presence into the scriptural literature as it was received into English 
translations together with the reflection of Protestant theologians, that re-composed the relation between justice and mercy, law and conscience, were the most subtle - and I believe not so investigated supporters of Tudors' hegemony and Stuart casuistry. I really believe that the making of Renaissance Bible, as the new scriptural text aimed to supply an autonomous criterion of validation for Law, Justice and their proper modulations, was the centre of Renaissance episteme.

2. This recall of the origins (as I have defined above a kind of foucaultian archaeology) discloses the hybrid nature of Equity and its proper and unsolvable relation with different fields: Equity's domain is not unique. As a consequence neither its meaning is compatible with a final unit; its manifold declensions compete for the construction of various cultures.

These arguments make me think that the study of Equity naturally requires an interdisciplinary approach and, moving from the perspective that belongs to me as a jurist, I'd like to underline how the several combinations well-known as "law and..." attain distinctive purposes with reference to our matter:

- law and literature: could be aimed to explore how literature (poetry, prose, drama, public panegyric) amplifies the culture of equity, how literary imagination is nourished and sustained by the various strains of equity so to emphasize the inner tensions and consequently to lead into a much deeper reflection on social ambiguities and moral contentions. But 
also the approach of law and literature could be oriented to discover the tropes of equity that characterize the literary writing, composing a specific rhetoric that directly or indirectly affects legal statements and legal reasoning

- law and politics: could be aimed to analyze how the morphology of a given legal system is structured to support a properly constituted political authority. In my view this issue is of significant importance for a legal understanding of the sovereignty especially in the famous Schmitt's definition as the power to decide on the state of exception. My argument is that the sharpness of the English distinction between Law and Equity until its proper institutionalization has to be defined according to a political theory of theorizing sovereignty. Equity arose and remained a separate system of rules administered by a separate body of Ministers as long as the King had to support his prerogatives against his Parliament and the raising corpus of Common Lawyers: Equity represented a concrete alternative to the armed wing for reasserting and making visible the presence of Sovereignty Power. In this perspective I'm convinced that the reassessment of English Equity could cast new light on our philosophical comprehension of the state of exception as a shifting device used to mark the boundaries between law and politics, or, in other words, to define law's threshold or limit concept. And in 
this meaning I read Agamben's definition of the state of exception as paradigm of government

- law and theology: could be aimed to bring to the surface the other side of legal thought discovering the ontological ambiguity of the origins. This research path - I think - leads us to understand how the separateness of the sacred developed. But it also unveils a kind of heideggerian nostalgia of the Law for that origin which willed to emancipate from. In such a view the shadow of the Sacred with its more or less extensive presence could variously conform the underlying structure of legal systems.

Now in my view the connection of these different approaches could have a considerable impact on the disembodiment of legal traditions. In fact, if we deprive traditions of that degree of self-consciousness required for their construction, we are confronted with many types of languages that factually shape the political debate. Consequently I prefer replace the concept of tradition with the notion of language. This plan entails the sacrifice of the historically recurrent demand for coherence, but at the same time it does not jeopardize the non-neutral nature of language. On the contrary if, as has been suggested, terminology is the properly poetic moment of thought, then terminological choices can never be neutral.

On this ground I conceive Politics as the dissimilar and unrepeated morphe of the historical existence, structured by the means of rival languages and competing theoretical modes. 
Applying the general considerations I have developed above to the specific comprehension of the history of English Legal System I'd like to suggest 3 main ideas or starting points for a broader reflection.

\section{1) the mixed nature of Equity in English constitutional settings,} that recalls its hybrid genealogy. I mean that Equity was the key factor to support and forge constitutional conflicts both between the Crown and his Parliament, and between the King and the Roman Pope.

In both cases Equity represented a kind of reserve (not only residuary) power granted to the King on a political and theological level, a kind - in my interpretation - of not only institutionalized but also naturalized power to decide the state of exception at the aim to reassert the sovereignty of the Crown against conflicting powers.

The duality of Law and Equity, as it took place in England in a unique way, made permanent the state of exception and bound the corresponding concept to the strictly juridical question of jurisdiction. To win against the corpus of Common Lawyers as the self-celebrating oracles of the Law and against the Pope as the Head of Catholic community with supreme spiritual jurisdiction, the King had to reaffirm his double prerogatives as the superior fountain of Justice and as the earthly mouthpiece of God's Law and will. And all that needed the creation of 'Equity' and Equity's jurisdiction.

My purpose is to stress how the structure of Equity had to deal with the theories that re-elaborated the Medieval distinction between 
the king's ordinary legal prerogatives and his emergency prerogative, so to understand the difference between a 'sovereign power over the Law' and a mere 'supplementary power' not operating through the Law, but having its boundaries defined by the Law.

So the history of English Legal System could be viewed as a polemical antagonism where the King's power outside the law came to be used as a power over the law.

It is no an historical accident that the $16^{\text {th }}$ and $17^{\text {th }}$ century were the Golden Age of Chancery, the era of its greatest judicial authority and political significance. In this perspective we could read Holdsworth's statement according which 'the strictly medieval conception of equity had a longer life in England than in any other country of Europe'. And I suggest to ponder over the use of the adjective medieval in this assertion: in fact it properly refers to the medieval, that is theological character of Tudor - Stuart's equity and at the same time it underscores the fact that Chancery gave institutional expression not only to the Crown's absolute prerogatives, but also to a transcendent moral virtue capable or called to reform the Law. As a consequence, the strongest importance of Chancery in this period meant that Christian justice and Christian social ethics remained a central business of the Crown.

To confirm my argument I can quote the clear assertions of different actors of English political debate. So Lambarde terms Equity 'the king's prerogative, or judicial power, his absolute and extraordinary pre-eminence of jurisdiction, the absolute and regal 
justice of the prince'; Ellesmere defines equity as 'the absolute prerogative which is in the kings'; Hake echoes Ellesmere's remark stating that equity is 'the absolute power of the Prince'; Bacon conceive of Chancery as the Court of the King's absolute power.

From the classical times, as Plato's Statesman makes clear, the path of Equity leads toward absolutism.

This passage could be closely linked to the second idea I suggest.

\section{2) Equity made use of specific languages that composed English} political debate to support royal prerogatives. To set a framework of rules as a source of sovereignty power, to constitute Equity in its autonomous existence, there was need of two specific languages: the language of theology and the language of civil law. And this for at least two kinds of reasons.

Firstly because theology and civil law provided the best arguments and rhetoric to justify absolute powers.

Christian royalism together with Platonism and Puritanism represented the dominant components of Tudor and Stuarts' political theology.

John Foxe was the principal responsible of the glorification of the Godly prince and his godly rule. He was the author of millenarian narrative of England as elect nation and Elizabeth as Christian Emperor 'through whose true, natural and imperial crown, the brightness of God's word was set up again to confound the dark and false-visored kingdom of Antichrist'. 
This was also the formulation of the 'order theory' to state the immutably hierarchical nature of political word so that the king's position in the microcosm of the commonwealth is equivalent to the position of God in the macrocosm.

Thomas Fuller in his the Holy State (1642) defended the King's claim to be the supreme Head on earth and at this aim he made use of a theological analogy that evoke the image of the King as the absent presence of Christ: in Princes, as on Mount Olivet, one beholds the direct imprint of holy, for in and through them 'the most high ruleth in the kingdoms of men'.

In Baxter and in James's writings there is an outstanding presence of the King's depiction as imitatio Dei or as Dei vicarius.

All these portrayal of the real source of royal authority matched with the flourishing presence of Equity, as a religious notion, in translations of the Bible which then inform its use in public and private worship.

So the theological language, coupled with the Reformers' anxiety, fed the growing creature of Equity and involved the massive transfer of sacrality from Church to Crown. Quoting Kantorowicz, we can say that 'the absolute prince stepped into the shoes of the Roman Pontiff'.

In the same direction, civil law traditions and language played a significant role in English debate on sovereignty. From the protean Corpus Iuris to Bodin's Six Books of Commonwealth, English civilians found historical principles and an unusual analytical clarity to develop 
a stronger revival of the theory of divine-right of the king and to judge the adequacy of codes of positive law measuring them against an independently-known set of laws of nature or reason, the same sources that master Equity's discourse.

But there is another reason that contributed to plot Equity's different talks. And this reason is deeply connected with the creation of the separate spheres of jurisdiction, so that, as a vivid image, different languages were responsible for the creation of different authorities deputed to declare the law.

The King's extraordinary or absolute power, as it was supported by the languages of theology and civil law, provided a basis for royal action in areas where the common law had no force: geographical possibly the high seas, and institutional - possibly the church. These were the elected spaces where Equity, as a kind of desacralized shekkinah, showed the Common Law's withdrawal.

On a rhetoric level the success of Common Law that performed the idea of an ancient constitution faced absolute (or even absolutist) claims supported by Equity. This was an historical tension impatient with the dismemberment of Common Law's mythology.

3) As a development of the previous reflections, Equity's different talks shaped not only a clear rhetoric but also a peculiar aestethics. 
At this regard I'd like to start with a quotation from Milsom's Historical Foundation of Common Law. Investigating the reasons of Equity's origin, Milsom suggest that the true start of Equity occurred after the medieval judicature forsook the divine test of oath and ordeal in favour of trial by jury which in effect replaced an infallible supernatural procedure with a notoriously fallible human one.

The urgent question became how could divine justice manifest itself: the same urgent question that in the Platonic myth confronts the polis after the shepherd-daemons forsake their human flocks.

Equity Courts emerged in response to this question, to the felt need to find or make room for the higher Justice of God to enter a new secularized legal system.

Equity Courts were elected spaces where the sacred reappeared, they were loci sacri.

And this consideration, once again, recalls the question of politics: the various attempt to locate the sacred within the constitution of a new political body have much to do with the politics of legitimation: the marking of the boundaries that isolate the loci sacri from the rest of the space, is to say that here is where the moral, spiritual and theological substance of God - but also of an anti-popish Christianity - enters the political field and transforms it.

The association of Equity Courts with ancient sites of divine judgement inspire the metaphors English writers use in describing Equity's space. 
Just to exemplify, Equity's sacral heritage is expressed by the images of the oracle and sanctuary.

In the first direction I can quote

- Lambarde when he says 'if only straight law should be administered, the help of God which speaketh in that oracle of Equity should be denied unto men that need it'

- Ellesmere (definition of Equity): Equitas est publici iuris moderatio a pectore Regis velut ab oraculo pretenda

- Hake: there fall out hard causes and cases uncertain and doubtful which are not defined by the law we are to fly to the magistrate from whom as from the tripos of Apollo we are to look for the sentence of equity.

In the second perspective, Equity as a sanctuary I can remember:

- Lambarde in his depiction of Star Chamber as place whereunto, in default of common help, men may fly for refuge as to certain sanctuary

- Hake where, speaking about Chancery, writes 'what greater safety can there be unto the persons there contending than the conscience of the Judge is and must be unto the same as a sanctuary of defence and succor'.

I'd like to stress that the concept of sanctuary has not only religious roots, but also a specific legal meaning insofar as it indicates a privileged place, a refuge where delinquent and debtors could flee and evade arrest, where the long arm of the law cannot lengthen. 
In this meaning we can read the verses of Daniel's 'To Sir Thomas Egerton' that use this powerful metaphor to describe the Court of Chancery:

'And therefore did those glorious monarchs (who divide with God the style of majesty for being God and had a core to do the world right and succour honestly) ordain this sanctuary whereunto th'opprest might fly, this seat of Equity).

Now the polemical antagonism between Common Law and Equity was manifested even in a struggle for the acquisition of the same rhetorical devices.

This was true with reference to the oracular metaphor.

Common Lawyers fought against the defenders of Equity to represent themselves as the ritual body where the divine pneuma issues, a new historical incarnation of a word that assumes to be the only true Law.

But this was true also with reference to the metaphor of sanctuary.

As we Know, Temple bar, the exclusive site where Common lawyers' life and doctrines took place, was exempted from every kind of jurisdiction.

To conclude, Equity's ontological ambiguity marks a kind of suspension, to use the words of Walter Benjamin a new epochè, a founding moment and a revolutionary opportunity and it depicts the Kafkian dismay before the Law that reasserts Law's proper transcendent inaccessibility. 


\section{REFERENCES}

Agamben, G., Homo Sacer. Sovereign Power and Bare Life, Stanford University Press, Stanford, 1998.

Assmann J., Potere e salvezza. Teologia politica nell'antico Egitto, in Israele e in Europa, Einaudi, Torino 2002.

Assmann J., Frühe Formen politischer Mythomotorik. Fundierende, kontrapräsentische und revolutionare Mythen, in HART D., ASSMANN J. (Hrsg.), Revolution und Mythos, Frankfurt 1992

Berman H.J., Law and Revolution: The Formation of the Western legal Tradition, Harvard University Press, Cambridge Mass., 1983.

Berman, H. J., The Historical Foundations of Law, in 54 Emory Law Journal. 2005, 13.

Berman, H.J., Law and Revolution, II. The Impact of the Protestant Reformations on the Western Legal Traditions, Belknap Press; Cambridge Mass., 2006.

Bodin, J., Six books of the commonwealth, Blackwell, Oxford, 1955.

Ellesmere, F. E., \& Collier, J. P., The Egerton papers: a collection of public and private documents chiefly illustrative of the times of Elizabeth and James I. from the original manuscripts, the property of the Right Hon. Lord Francis Egerton. Works of the Camden Society, no. 12, printed for the Camden society, [by J.B. Nichols and son], London, 1968.

Fortier, M., The Culture of Equity in Early Modern England. Aldershot, Hants, England, Ashgate, 2005.

Fortier, M., Equity and Ideas: Coke, Ellesmere, and James I, in 51 Renaissance Quarterly, 1998, pp. 1255-1281.

Foxe, J., Foxe and the English Reformation, 1539 - 1587. Marlborough, Matthew, 2003.

Foxe, J., \& Comber, T., Christus triumphans comoedia apocalyptica, Impensis Rob. Clavel, Londini, 1672.

Fuller, T., The Holy State, printed by R. Daniel for J. Williams, Cambridge, 1642.

Hake, E., Epieikeia, a dialogue on equity in three parts, Yale Law Library publications, no. 13. [New Haven], Yale University Press for the Yale Law Library, 1953. 
Hertzler J.R., The Abuse and Outlawing of Sanctuary for Debt in Seventeenth-Century England, in 14 The Historical Journal 3, 1971, pp. 467-477.

Holdsworth W.S., A History of English Law, Methuen \& Co., London 1924.

Hooker R., Of the Laws of Ecclesiastical Polity, J.M. Dent \& Co., London 1907.

Kantorowicz, H., The definition of law, Cambridge University Press, Cambridge, 1958.

Kantorowicz, H., \& Majetti, R. La lotta per la scienza del diritto, R. Sandron, Milano-Palermo-Napoli, 1908.

Kantorowicz, H., I due corpi del re: l'idea di regalità nella teologia politica medievale, Einaudi, Torino, 1989.

Lambarde W., Archeion: or, A Discourse upon the High Courts of Ivstice in England, printed by E.P. for Henry Seile, dwelling at the Tygers-head in St. Pauls Church-yard, London, 1635.

Milsom, S. F. C. Historical Foundations of the Common Law, Butterworths, London, 1969.

Schmitt C., Il nomos della terra, Adelphi, Milano 1991.

Schmitt C., Politische Theologie. Vier Kapitel zur Lehre von der Souveränität, Duncker \& Humblot, Berlin 1922.

Selden, J. Table-talk being the discourses of John Selden, Esq., or his sense of various matters of weight and high consequence relating especially to religion and state. printed for E. Smith, London, 1689. 